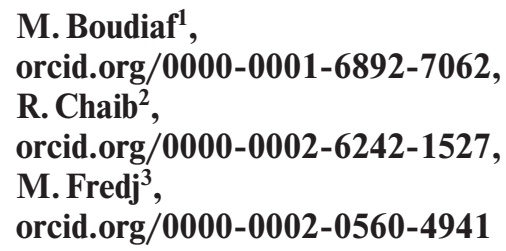

1 - Laboratory of Materials, Geotechnics, Housing and Urbanism, University of 20th August 1955, Skikda, Algeria, email: boudiafastral@gmail.com

2 - Brothers Mentouri University-Constantine 1, Algeria

3- Abderrahmane Mira University, Bejaia, Algeria

\title{
ASSESSMENT OF POTENTIAL DANGERS OF INSTALLATIONS AT RHOURDE NOUSS STATION WITHIN THE FRAMEWORK OF THE LAW 45/DG (OUARGLA, ALGERIA)
}

Purpose. According to the SONATRACH group's requirements, a hazard study should be carried out conforming to Law 45/ DG in order to manage risk situations better and to ensure maximum operational safety.

Methodology. The work presents modeling of accident scenarios through the ALOHA software. The identification and characterization of potential hazards of the facilities are carried out by the XRISK software while using the preliminary risk analysis method (PRA) and the bow tie method (in a horizontal plane).

Finding. An assessment of the socio-economic impact in the event of an accident in the hydrocarbon industry is given as well as recommendations to avoid unforeseen consequences.

Originality. For the first time at SONATRACH, the LOPA software has been used to model accident scenarios in the hydrocarbon industry. The latter refers to high-risk industries where every activity, whether industrial or commercial, is subject to incidents or serious situations that could seriously disrupt the operation of the organization, or even damage or destroy it.

Practical value. Sensitive elements have been identified, which respectively include the station staff, the DSP agents on duty (digital signal processing), the subcontractors, i.e. a permanent population of 30 people on average. The occurrence of the potential major accidents identified in the risk analysis would cause the gas compression to stop at Rhourde Nouss station. Thus, there is a pressure drop at the level of the gas pipelines, which reduces the gas flow significantly, while its extent and duration will depend on the restarting of the station. Furthermore, the effects of damage to the equipment concerned could result in a significant cost for their replacement within a reasonable time.

Keywords: XRISK, ALOHA, risk assessment, prevention, and hydrocarbon industry

Introduction. In the field of industrial process safety management, the analysis and assessment of vulnerability is a very important step in assessing risk in the presence of affected targets, whether human, environmental or material [1], particularly with the increase in the number of homes close to large high-risk industrial installations. Most of the available studies on vulnerability focus mainly on the sensitivity of areas to natural risks or threats of malicious intent and terrorism while neglecting the vulnerability analysis of major industrial risks $[2,3]$. Consequently, throughout the world, safety and risk prevention have become an essential concept for any entity, in particular to guarantee the safety of goods and people and to preserve the environment $[4,5]$. As a result, risk control is now linked to the legal and financial responsibility, which weighs more and more on business leaders, organizations, insurance funds and even individuals as employees [6]. However, the risk is a dynamic notion of contingency. Consequently, it is essential to know the safety system that best contributes to ensuring the operating safety of the installations and the safety of the working environment. From now on, certain risks, if they occur, have serious effects on people (fatality, injuries), property (materials and production tools), and the environment (residents and pollution) [7]. Immediately, a new issue arose: that of the risks generated by the implementation of technologies. However, the oil and gas industry is subject to a wide variety of incidents or serious situations that can seriously disrupt its operation, or damage and even destroy it. As a result, high-risk facilities must be operated under rigorous safety and security conditions. This is why the primary duty of the operator, in facilities liable to be the site of a major accident, is to endeavor to control the risks. It is a preventive logic to prevent the hazard or reduce the effects of a possible event on people, property, and the environment; this logic fits naturally into a sustainable development approach since prevention strives to reduce the economic, social, and environmental consequences

(C) Boudiaf M., Chaib R., Fredj M., 2021 of reckless development of society, unlike repair, which, necessarily, follows a crisis. For this, we must know the nature of the risk, the events that could cause an accident and its consequences, the objective of our study. Thus, risk assessment is required and should be carried out for any activity, task, and so on before the activity begins [8]. From now on, risk prevention has become a major issue for any industrial activity and a priority for any industrial activity, or even any business. A priori, the assessment of these risks constitutes one of the main levers for progress in risk prevention within a company. This is an opportunity to initiate a prevention process.

In Algeria, in recent years, the hydrocarbon industries have been the source of serious accidents and major calamities where fires and explosions have caused serious impacts and effects on people, property, and the environment $[9,10]$. As an example we can consider the GN1K explosion of Skikda, which left 21 deaths, 72 injured and considerable material and environmental damage [11, 12]. This disaster made it possible to sensitize both authorities and populations to the risks associated with certain industrial activities (chemicals, petroleum, pyrotechnics, food processing, and so on). In addition, this industry is the first vector of novelty, the first recipient of the most diverse services, an essential point of support for national economic growth, for the relief and vitality of the national economic fabric. In short, this industrial sector is at the heart of the economic development and employment of our country $[13,14]$. In addition, the major poles of the hydrocarbon industry such as the sites of Skikda, Arzew, Hassi-Messaoud, and Hassi-R'Mel are sources of permanent dangers given its proximity to urbanized areas where certain domino effects can be manifested. From now on, in-depth knowledge of the risks is required. This makes it possible to better assess the potential consequences of the phenomena and to put in place appropriate prevention or protection measures taking into account the vulnerability of the site in question.

However, as the hydrocarbon industry is classified among the high-risk industries where each activity, whether industrial or commercial, is subject to a wide variety of incidents or seri- 
ous situations that could seriously disrupt its operation, or damage it and even destroy it. These incidents can turn into major industrial accidents [15]. Thus, education and training in the prevention of occupational risks are essential in this strategic sector of the country. As a result, industrial hygiene and safety are imposed more rigorously and become a fundamental factor and a military component in this type of industry.

Thus, in the context of oil exploitation/production, this implies targeting objectives concerning the prevention and control of industrial risks for the respect of hygiene, health, safety and the environment in order to make the production of hydrocarbons and petroleum equipment more reliable and sustainable. Subsequently, Directive 45/DG, requires all structures and units of the SONATRACH group to carry out hazard studies, by implementing all the human and material resources necessary, with an update of these studies following the changes and modifications to the installation, the objectives of this work. As a field of application and given the various modifications experienced by the RHOURDE NOUSS compressor station, it has become imperative to carry out a hazard study in order to comply with the law, to better manage risk situations and ensure maximum safety in operation [9]. As a result, we have subjected ourselves to studying part of the installation: the compressor station given its importance in the production process. After fieldwork, we are convinced that, given the difficulties encountered in the field, we cannot fully estimate our study. Despite this, the work offers the first local experience (since all existing studies are carried out by foreign consultancies) on a very recent subject in the compressor station.

Presentation of the Field of Study. Within the SONATRACH Group, the Pipeline Transport Activity (PTA) undertakes a mission of delivering hydrocarbons (crude oil, Gas, GPL and condensate), from production areas to storage areas, GNL and GPL complexes, refineries, oil ports as well as to importing countries while respecting the conditions of safety and environmental protection (Fig. 1).

The PTA manages a large network of hydrocarbon transport infrastructure comprising 79 stations divided into 48 pumping stations ( 35 crude, 3 condensate and 10 GPL) and 31 Natural Gas (NG) compressor stations, Table 1.

The operation division of PTA is organized into several regions, of which the Ain-Aménas region RTI is responsible for the operation, maintenance of the network and monitoring of extension projects in the Ain-Aménas region. The Rhourde Nouss station is one of the Gas compressor stations between Alrar and Hassi R'Mel, Fig. 2.

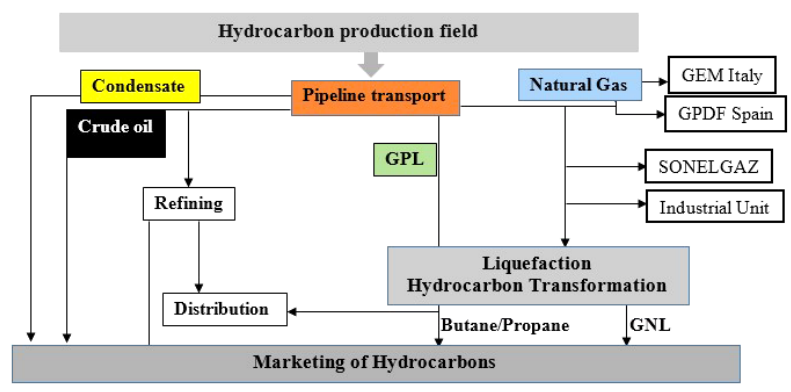

Fig 1. Overview of the Pipeline Transport Activity (PTA)

Table 1

Hydrocarbon stations under TRC

\begin{tabular}{|c|c|c|c|c|}
\hline \multicolumn{3}{|c|}{ Pumping stations } & $\begin{array}{c}\text { Compressor } \\
\text { Stations }\end{array}$ & Total \\
\hline Gross & Condensate & GPL & Natural Gas (NG) & \\
\hline $\begin{array}{l}35 \text { with satellite } \\
\text { stations }\end{array}$ & 03 & 10 & 31 & 79 \\
\hline
\end{tabular}

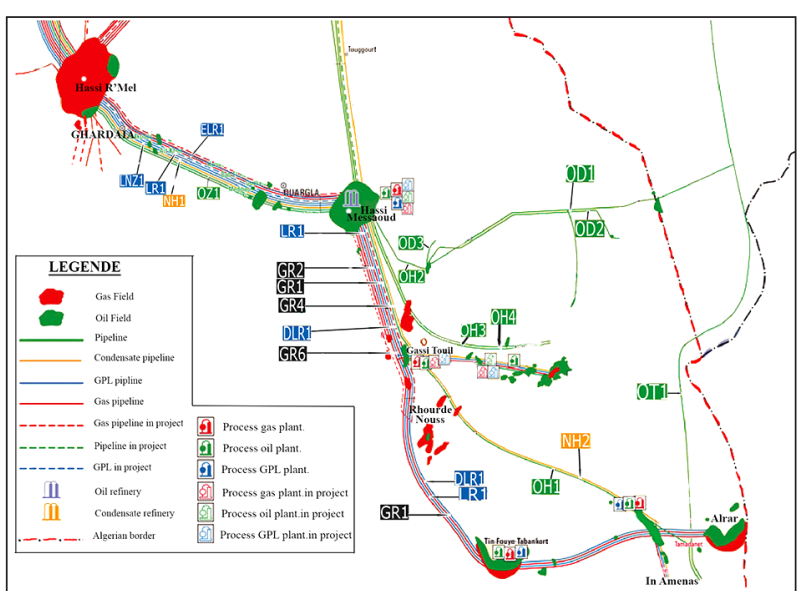

Fig. 2. Geographical location of the Rhourde Nouss station

Work methodology. High-risk installations must be operated under strict security conditions. This is why the primary duty of the operator, in facilities liable to be the site of a major accident, is to endeavor to control the risk. For this, they must know the nature of the risk, the events that could cause an accident and the consequences that an accident could have. The best way to answer these questions is to conduct a hazard study. It is a question of determining why accidents can occur and how it is possible to avoid them or at least to mitigate the consequences. There are many ways to do this duty.

The most effective methods in this field of activity are systematic analyses of deviations or failures [16]. Thanks to this type of analysis, it is possible to understand which are the most risky stages of the process and, if necessary, to propose appropriate corrective and preventive measures.

In this study, XRISK software was used while applying the Preliminary Risk Analysis (PRA) method and the bow tie method (NP). The PRA allowed us to direct the analyses to the critical points, then we used the NP to carry out the operation and control the risks involved. To finalize the work and model the three risk categories (toxic gas dispersion, fire, and gas explosion), we called on the ALOHA software (Areal Locations of Hazardous Atmospheres) to highlight the recommendations afterwards. To carry out our study, we called on the XRISK software [17]. The latter is a tool that makes it possible to model a system according to the choice and/or the needs of teaching on Functional analysis, Structural-functional analysis, and process approach. These approaches make it possible to describe the installation being analyzed. The model is constructed explicitly or implicitly when adding risks. It is built iteratively. Two dangers were respectively retained by this study, the dangers related to the turbocharger building (S01) and those related to the GR1 pipeline 48. The consequences of the materialization of major scenarios are calculated in terms of effect distances, and the essential aspects of the modeling are reported in the following:

1. The calculations focused on the three types of central feared event (CRE): gas leak, fire and explosion.

2. When the choice is allowed, the major conditions have been voluntarily chosen as calculation hypotheses.

3. The two cases of gas ignition were examined: instantaneous ignition upon exiting the gas and delayed ignition.

4. Due to the sparse layout of the facilities, all accident cases are modeled in an unconfined environment.

5 . The calculation model imposes a constraint for the choice of the minimum dimension of pipe length, established at $850 \mathrm{ft}$. This usually leads to an exaggeration of the effect distances.

Results and discussions of the accident modeling. The consequences of various accident scenarios that could occur at the turbocharged building and 48 -inch pipeline facilities were assessed. The results are presented in the form of graphs. For 
each of the scenarios identified and positioned in category II of the criticality matrix, the feared effects are quantified using the ALOHA software.

\section{Data for Modeling, Data Site:}

Location: RHOURDE NOUSS, ALGERIA

Building Air Exchanges per hour: 1.02 (user specified)

Time: May 19, 2018 12:32 hours ST (using computer clock)

Natural gas consists mainly of methane $\left(\mathrm{CH}_{4}>80 \%\right.$ by mass molar), and will be modeled as methane.

Chemical Name: METHANE Molecular Weight: $16.04 \mathrm{~g} / \mathrm{mol}$ TEEL-1: $3000 \mathrm{ppm}$, TEEL-2: $5000 \mathrm{ppm}$, TEEL-3: $200000 \mathrm{ppm}$ LEL: 44,000 ppm, UEL: 165,000 ppm

Ambient Boiling Point: $-161.9^{\circ} \mathrm{C}$

Freezing Point: $-182.5^{\circ} \mathrm{C}$.

Atmospheric Data: (Manual Input of Data).

Wind: 10 miles/hour from $5^{\circ}$ true at 3 meters

Ground Roughness: open country Cloud Cover: 5 tenths

Air Temperature: $35^{\circ} \mathrm{C}$, Stability Class: D

No Inversion Height Relative Humidity: $5 \%$.

Scenario No. 1: explosion/fire in a Turbocharger (TC) building.

A. Threat zone: Toxic atmosphere (Fig. 3, a).

Model Run: Gaussian

- Red: 45 meters (200 000 ppm = TEEL-3)

Note: Threat zone was not drawn because effects of near-field patchiness make predictions less reliable for short distances.
- Orange: 309 meters $(5000 \mathrm{ppm}=$ TEEL-2)

- Yellow: 410 meters $(3000 \mathrm{ppm}=$ TEEL-1).

B. Threat Zone: Atmosphere - Flammable (Fig. 3, b)

Threat Modeled: Flammable Area of Vapor Cloud Explosion (VCE)

Model Run: Gaussian

Red: 182 meters --- $(26,400 \mathrm{ppm}=60 \%$ LEL $=$ Flame Pockets $)$

Yellow: 485 meters --- $(4,400 \mathrm{ppm}=10 \%$ LEL $)$.

C. Threat Zone: on pressurization by VCE (Fig. 3, c)

Source strength:

- Flammable gas escaping from pipe (not burning)

- Pipe diameter: 48 inches, pipe length: 850 feet

- Unbroken end of the pipe is closed off

- Pipe roughness: rough hole area: 3.875 square inches

- Pipe press: 70 atmospheres Pipe Temperature: $60{ }^{\circ} \mathrm{C}$

- Release duration: ALOHA limited the duration to 1 hour

- Max average sustained release rate: 1500 kilograms/min (averaged over a minute or more)

- Total amount released: 12248 kilograms.

Threat zone. Threat modeled: Overpressure (blast force) from vapor cloud explosion (VCE)

Type of ignition: ignited by spark or flame

Level of congestion: congested

Model run: Gaussian

Red: LOC was never exceeded $(8.0 \mathrm{psi}=$ destruction of buildings)

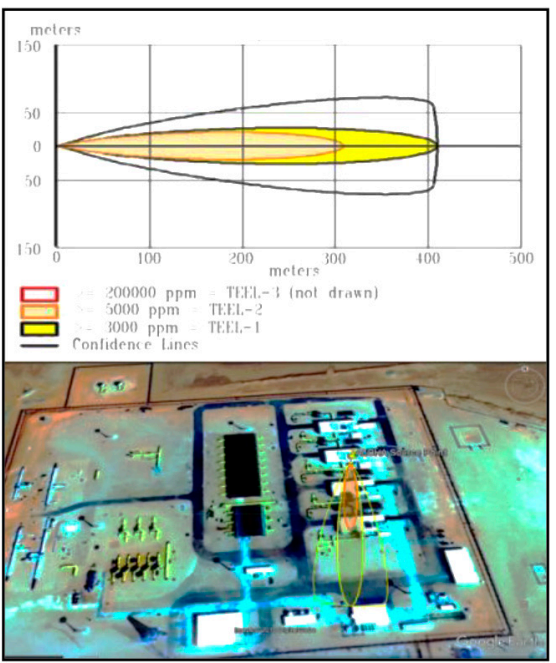

$a$

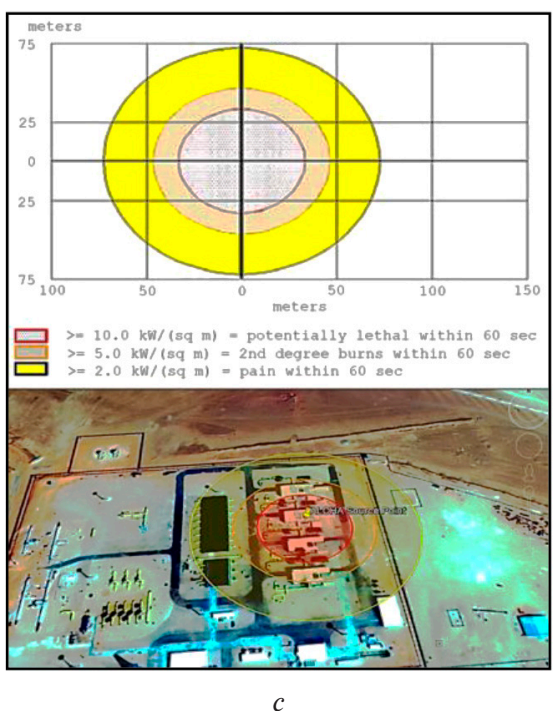

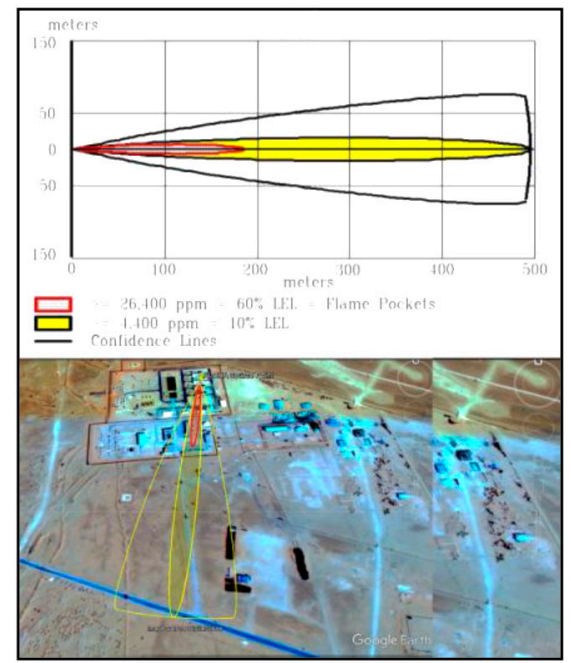

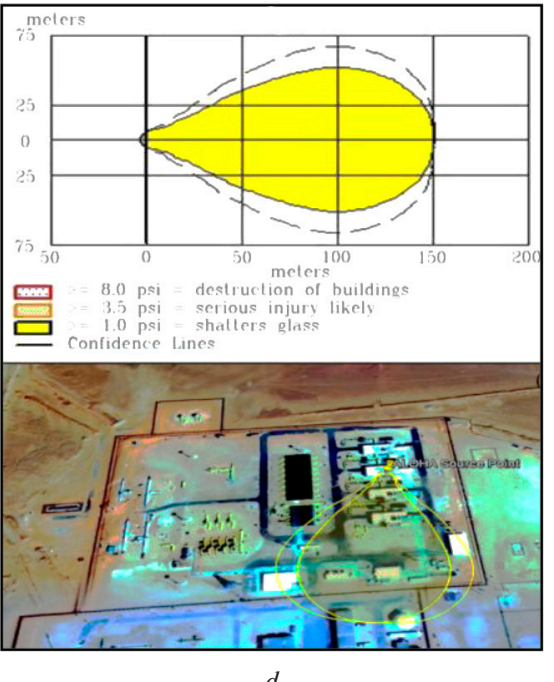

Fig. 3. Results of the dispersion modeling of explosion/fire in a turbocharger building at the TC level:

$a$-Toxic atmosphere; $b$-Atmosphere-flammable; $c$-On pressurization by VCE; $d$ - Thermal radiation by torch fire 
Orange: LOC was never exceeded $(3.5 \mathrm{psi}=$ serious injury likely)

Yellow: 152 meters ( $1.0 \mathrm{psi}=$ shatters glass $)$.

D. Threat zone: thermal radiation by torch fire.

Threat modeled: Thermal radiation from jet fire (Fig. 3, $d$ ) Red: 34 meters $\left(10.0 \mathrm{~kW} / \mathrm{m}^{2}=\right.$ potentially lethal within $60 \mathrm{se}-$ conds)

Orange: 47 meters $\left(5.0 \mathrm{~kW} / \mathrm{m}^{2}=2\right.$ nd degree burns within 60 seconds)

Yellow: 73 meters $\left(2.0 \mathrm{~kW} / \mathrm{m}^{2}=\right.$ pain within 60 seconds $)$

SOURCE STRENGTH: Flammable gas is burning as it escapes from pipe

Scenario No. 2: Fire at PIPE GR1, source strength.

Flammable gas is burning as it escapes from pipe

Pipe diameter: 48 inches Pipe Length: 850 feet

Unbroken end of the pipe is closed off

Pipe roughness: rough Hole Area: 3.875 square inches

Pipe press: 50 atmospheres pipe temperature: $35^{\circ} \mathrm{C}$

Max flame length: 4 meters

Burn duration: ALOHA limited the duration to 1 hour

Max burn rate: 1,240 kilograms/min

Total amount burned: 9,406 kilograms.

Threat Zone. Threat modeled: thermal radiation from jet fire (Fig. 4)

Red: 29 meters $\left(10.0 \mathrm{~kW} / \mathrm{m}^{2}=\right.$ potentially lethal within 60 seconds)

Orange: 41 meters $\left(5.0 \mathrm{~kW} / \mathrm{m}^{2}=2^{\text {nd }}\right.$ degree burns within 60 seconds)

Yellow: 63 meters $\left(2.0 \mathrm{~kW} / \mathrm{m}^{2}=\right.$ pain within 60 seconds $)$.

Effects of accidents: the results of accidents are grouped together in the following Tables (Tables 2, 3).

The hierarchy of the accidents selected according to the risk distances specific to each scenario gives the following classification (Table 4).

Study result. As a result of socio-economic impacts in the event of an accident, and given that the station is located in a desert region with no industrial infrastructure or establishment capable of receiving the public. In addition, the area adjacent to the station does not contain any vulnerable element likely to be directly or by domino effect affected by a major accident. However, the sensitive elements are, on the other hand, the staff of the station, the DSP agents in post, the subcontractors, that is to say a population of 30 people on average. Subsequently, the occurrence of the potential major accidents identified in the risk analysis would cause the gas compression to stop at the station. The gas transferred from the TFT station would be returned to the GR1 and GR2 pipes, with a bypass from the Rhourde Nouss station. The downside would be a

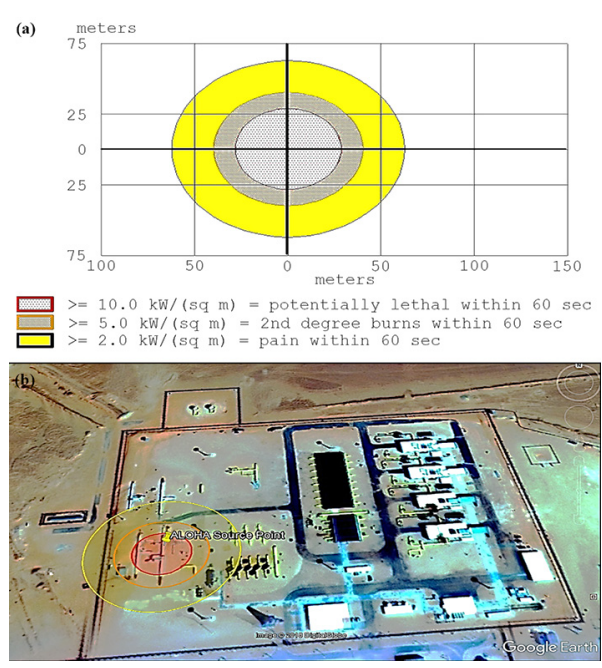

Fig. 4. Results of the dispersion modeling of torch fire at the PIPE GR1 level

Non-ignited methane leak at the start

\begin{tabular}{|c|c|c|c|c|}
\hline $\begin{array}{l}\text { Feared } \\
\text { event }\end{array}$ & Effect & $\begin{array}{l}\text { Gas } \\
\text { ignition } \\
\text { source }\end{array}$ & $\begin{array}{c}\text { Effect } \\
\text { Distances }\end{array}$ & $\begin{array}{c}\mathrm{CH}_{4} \\
\text { Emission } \\
(\mathrm{kg})\end{array}$ \\
\hline \multirow{3}{*}{ 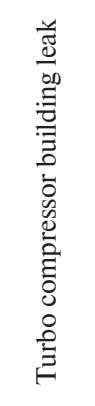 } & Explosion & $\begin{array}{l}\text { Flame } \\
\text { or Spark }\end{array}$ & ZONE3 : $152 \mathrm{~m}$ & \multirow[t]{3}{*}{12.250} \\
\hline & $\begin{array}{l}\text { Flammability } \\
\text { zone }\end{array}$ & $\begin{array}{l}\text { Flame } \\
\text { or spark }\end{array}$ & $\begin{array}{l}\text { ZONE A : } 182 \mathrm{~m} \\
\text { ZONEB : } 485 \mathrm{~m}\end{array}$ & \\
\hline & Toxic cloud & $\begin{array}{l}\text { Flame } \\
\text { or spark }\end{array}$ & $\begin{array}{l}\text { TOXIC ZONE } \\
\text { TEEL3 }= \\
=2.105 \mathrm{ppm}: 45 \mathrm{~m} \\
\text { TEEL2 }= \\
=5.103 \mathrm{ppm}: 309 \mathrm{~m} \\
\text { TEEL1 }= \\
=3.103 \mathrm{ppm}: 410 \mathrm{~m}\end{array}$ & \\
\hline
\end{tabular}

Table 3

Leakage of methane ignites initially

\begin{tabular}{|l|l|l|l|c|}
\hline \multicolumn{1}{|c|}{$\begin{array}{c}\text { Feared } \\
\text { event }\end{array}$} & Effect & $\begin{array}{c}\text { Gas } \\
\text { ignition } \\
\text { source }\end{array}$ & $\begin{array}{c}\text { Effect distances } \\
(\mathrm{m})\end{array}$ & $\begin{array}{c}\mathrm{CH}_{4} \\
\text { Emission } \\
(\mathrm{kg})\end{array}$ \\
\hline $\begin{array}{l}\text { Turbo- } \\
\text { compressor } \\
\text { building leak }\end{array}$ & $\begin{array}{l}\text { Fire } \\
\text { flash fire }\end{array}$ & $\begin{array}{l}\text { flame } \\
\text { or spark }\end{array}$ & $\begin{array}{l}\text { ZONE A }: 34 \mathrm{~m} \\
\text { ZONE B }: 47 \mathrm{~m} \\
\text { ZONE C }: 73 \mathrm{~m}\end{array}$ & 12.250 \\
\hline $\begin{array}{l}\text { Pipe leak } \\
\text { 48" GR1 }\end{array}$ & $\begin{array}{l}\text { Fire } \\
\text { flash fire }\end{array}$ & $\begin{array}{l}\text { flame } \\
\text { or spark }\end{array}$ & $\begin{array}{l}\text { ZONE A }: 29 \mathrm{~m} \\
\text { ZONE B }: 41 \mathrm{~m} \\
\text { ZONE C : 63 m }\end{array}$ & 9.406 \\
\hline
\end{tabular}

Table 4

The risk distances specific to each scenario

\begin{tabular}{|c|c|c|c|}
\hline $\mathrm{N}^{\circ}$ & \multicolumn{2}{|l|}{ Scenario } & Effect distance \\
\hline \multicolumn{4}{|c|}{ for the explosion (gas dispersion not ignited at the start) } \\
\hline 01 & \multicolumn{2}{|c|}{ Turbo compressor building - VCE (No. 1) } & $130 \mathrm{~m}$ (Zone 3$)$ \\
\hline \multicolumn{4}{|c|}{ For flash fire (dispersion of ignited gas) } \\
\hline 01 & $\begin{array}{l}\text { Turbo compressor building - } \\
\text { VCE (No. 1) }\end{array}$ & $\begin{array}{l}\text { Instant } \\
\text { fire }\end{array}$ & 01 \\
\hline 02 & PIPE 48”, GR1 & $\begin{array}{l}\text { Instant } \\
\text { fire }\end{array}$ & 02 \\
\hline
\end{tabular}

pressure drop at the level of the gas pipelines reducing the gas flow in a significant way, the size and duration of which will depend on the restarting of the Rhourde Nouss station. Furthermore, the effects of damage to the equipment concerned could result in a significant cost for their replacement within a reasonable time.

Conclusions. This study focused on the analysis of the risks generated by the Rhoude Nouss compressor station where a detailed study on major accident scenarios using the ALOHA software was carried out. The potential consequences of the effects on people and the environment were assessed from the inventory carried out in these areas and are contained within the station. The risk is linked to the nature of the fluid treated in the station. $\mathrm{CH}_{4} \mathrm{Gas}$ is flammable and explosive. The dangers arise from a loss of containment of a facility containing gas such as piping, turbochargers and ancillary equipment. The gas escaping at a pressure greater than 50 bars can disperse in a flaming form from the start causing a flash fire effect. When the gas is released unignited initially, the explosion (by detonation) or flammability zone scenarios are possible.

The risk analysis thus identified two critical accidents deemed to be representative. 
Explosion/Fire at the turbocharger building

Fire at pipeline 48 " GR1.

The identification of the risk factors in this study showed that:

1. The risk factors present in the RHOURDE NOUSS station are linked to the flammability of the fluids treated: natural gas and condensate in the event of loss of containment or physical integrity.

2. The potential dangers associated with the equipment come mainly from the operating conditions of transporting large quantities of $\mathrm{NG}$ to the compressor station.

3. The accidents referenced in the accidentology study are mainly characterized by events linked to gas leaks caused by rupture on a fitting, seal, flange, valve or shocks by external elements.

4. The risks have been reduced at the source in order to reduce the potential dangers.

5. The risk analysis sought to comprehensively review all the causes and consequences of physically likely drifts with regard to the facilities. The rating criteria in terms of probability of occurrence and severity associated with each of its potential drifts made it possible to identify all of the feared events considered "to be controlled". This is possible thanks to the following:

- precautions for the design, construction, operation, inspection and maintenance of installations;

- the control loops and the various sensors and associated safety interlocking;

- the training and training of operating and maintenance personnel, in normal or degraded mode;

- the means of protection or control of the consequences implemented in the event of an accidental event, such as fire hydrants, restricted access to facilities, means of intervention, and so on.

6. The means of prevention, detection, protection and limitation of the effects put in place are relatively sufficient to ensure the safety of the installation; nevertheless, the implementation of the recommendations proposed in this brief will guarantee and provide potential measures to reduce risks, to arrive at safer values.

\section{References.}

1. Villa, V., Paltrinieri, N., Khan, F., \& Cozzani, V. (2016). Towards dynamic risk analysis: A review of the risk assessment approach and its limitations in the chemical process industry. Safety science, 89, 77-93.

2. Quigley, K., Bisset, B., \& Mills, B. (2017). Too critical to fail: How Canada manages threats to critical infrastructure ( $1{ }^{\text {st }} \mathrm{ed}$.). McGill-Queen's University Press.

3. Legrand, T., \& Hufnagel, S. (2015). Risk and resilience: international approaches to vulnerable infrastructure protection. Emerging Strategic Trends in Asia.

4. Hollnagel, E. (2018). Safety-I and Safety-II: The past and future of safety management ( $1^{\text {st }}$ ed.).CRC press, ISBN 9781315607511.

5. Podgórski, D., Majchrzycka, K., Dąbrowska, A., Gralewicz, G., \& Okrasa, M. (2017). Towards a conceptual framework of OSH risk management in smart working environments based on smart PPE, ambient intelligence and the Internet of Things technologies. International Journal of Occupational Safety and Ergonomics, 23(1), 1-20. https://doi.org/10.1080/1 0803548.2016.1214431.

6. Kharzi, R., Chaib, R., Verzea, I., \& Akni, A. (2020). A Safe and Sustainable Development in a Hygiene and Healthy Company Using Decision Matrix Risk Assessment Technique: a case study. Journal of Mining and Environment, 11(20), 363-373. https://doi.org/10.22044/jme.2020.9156.1807.

7. Hellas, M., Chaib, R., \& Verzea, I. (2019). Artificial intelligence treating the problem of uncertainty in quantitative risk analysis (QRA). Journal of Engineering, Design and Technology, 18(1), 40-54. https://doi.org/10.1108/JEDT-03-2019-0057.
8. Grigoli, F., Cesca, S., \& Priolo, E. (2017). Current challenges in monitoring, discrimination, and management of induced seismicity related to underground industrial activities: A European perspective. Reviews of Geophysics, 55(2), 310-340. 9. Ait Ouffroukh, L., Chaib, R., Verzea, I., \& Khochmane, L. (2017). Analysis of Risk and the Strengthening of the Safety Technical Barriers: Application of Skikda (Algeria) Oil Refining Complex. World Journal of Engineering. https://doi. org/10.1108/WJE-02-2017-0031.

10. Seddik, H. M., Chaib, R., \& Verzea, I. (2018). Quantitative Risk Analysis Detailed Study of Thermal and Overpressure Risks Case Study. RECENT, 19(3(56)), 28-136. https:// doi.org/10.31926/RECENT.2018.56.128.

11. Hammouya, A., Kabouche, A., \& Chaib, R. (2019). Study of Drain Barrier Effect on Hydrocarbons Hazards. Journal of Failure Analysis and Prevention, 19(5), 1475-1486. https://doi. org/10.1007/s11668-019-00748-1.

12. Hassani, M., Chaib, R., \& Bouzerara, R. (2018). Reduction of the Vulnerability Zone of a Major Industrial Risk. Case of BLEVE in LPG Storage Sphere Hassi R'Mel, Algeria. $R E$ CENT, 19(2(55)), 089-096. https://doi.org/10.31926/RECENT.2018.55.089.

13. Akni, A., Chaib, R., \& Verzea, I. (2020). Contribution to the Evaluation of Safety Barriers at the Treatment Section 'STRIPPER'. Recent, 62, 100-111. https://doi.org/10.31926/ RECENT.2020.62.100.

14. Hassani, M., Chaib, R., \& Bouzerara, R. (2020). Vulnerability Assessment for Major Industrial Risks Proposal for a Semi quantitative Analysis Method (VAMIR) Application: Oil and Gas Industry. Journal of Failure Analysis and Prevention. https://doi.org/10.1007/s11668-020-00960-4.

15. Ait Ouffroukh, L., Chaib, R., \& Verzea, I. (2019). Study of the Conformity and Dimensioning of an Anti-Fire Network in a Hydrocarbon Depot. Recent, 58. https://doi.org/10.31926/ RECENT.2019.58.056.

16. Attar, M., \& Hammat, M. (2021). Algeria's Hydrocarbon Potential; Contribution from SONATRACH Exploration Division. Retreived from http://www.searchanddiscovery.com/ abstracts/html/1994/annual/abstracts/0096b.htm.

17. Flaus, J.M. (2014). Logiciel XRisk pour l'analyse systémique des risques pilotée par modèle. Retreived from https://lpsc-indico.in 2 p3.fr/event/1086/contributions/222/attachments/217/252/Atelier141124-JMFlaus-Xrisk.pdf.

\section{Оцінка потенційної небезпеки установок на станщії Рурд Нусс у рамках закону 45/DG (Уаргла, Алжир)}

\section{М. Будіа $\phi^{1}$, Р. Чайб ${ }^{2}$, М. Фредж⿻}

1 - Лабораторія матеріалів, геотехніки, житлового будівництва та містобудування, Університет 20 серпня 1955 р, м. Скікда, Алжир, e-mail: boudiafastral@gmail.com 2 - Університет Константина 1, м. Константина, Алжир 3 - Університет Абдеррахмане Міра, м. Беджая, Алжир

Мета. Відповідно до вимог компанії SONATRACH груп, необхідно провести дослідження на випадок можливої небезпеки, відповідно до закону 45/DG, із метою кращого управління ризиками й забезпечення максимальної експлуатаційної безпеки.

Методика. Робота являє собою моделювання аварійних сценаріїв за допомогою програмного забезпечення ALOHA. Ідентифікація й характеристика потенційних небезпек об'єктів виконується за допомогою програмного забезпечення XRISK із використанням методу попереднього аналізу ризиків (ПАР) і методу «Краватка-метелик» (у горизонтальній площині).

Результати. Дана оцінка соціально-економічного впливу в разі аварії у вуглеводневій галузі промисловос- 
ті та рекомендації, щоб уникнути непередбачених наслідків.

Наукова новизна. Полягає в моделюванні аварійних сценаріїв у вуглеводневій галузі промисловості. Остання належить до галузей із високим рівнем ризику, де кожен вид діяльності, будь то промисловий або комерційний, схильний до найрізноманітнішим інцидентів або серйозних ситуацій, що можуть серйозно порушити іï функціонування або навіть пошкодити та знищити.

Практична значимість. Визначення сприймаючих елементів, що включають персонал станції, чергових агентів ЦОС (цифрова обробка сигналів), субпідрядників, тобто постійно працюючих співробітників, у середньому 30 чоловік. Виникнення потенційних великих аварій, визначених у аналізі ризиків, призведе до зупинки стиснення газу на станції Рурд Нусс. Таким чином, на рівні газопроводів відбувається падіння тиску, що значно знижує потік газу, а його ступінь і тривалість будуть залежати від перезапуску станції. Крім того, наслідки пошкодження відповідного обладнання можуть призвести до значних витрат на його заміну в об'єктивно необхідний термін.

Ключові слова: XRISK, ALOHA, оцінка аварійних ситуацій, попередження, вуглеводнева галузь

\section{Оценка потенциальной опасности установок на станции Рурд Нусс в рамках закона 45/DG (Уаргла, Алжир)}

\author{
М. Будиаф $\phi^{1}$, Р. Чайб $\sigma^{2}$, М. Фредж
}

1 - Лаборатория материалов, геотехники, жилищного строительства и градостроительства, Университет 20 августа 1955 г., г. Скикда, Алжир, e-mail: boudiafastral@ gmail.com

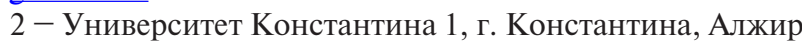
3 - Университет Абдеррахмане Мира, г. Беджая, Алжир

Цель. Согласно требованиям компании SONATRACH групп, необходимо провести исследование на случай возможной опасности в соответствии с законом 45/DG, с целью лучшего управления рисками и обеспечения максимальной эксплуатационной безопасности.

Методика. Работа представляет моделирование аварийных сценариев с помощью программного обеспечения ALOHA. Идентификация и характеристика потенциальных опасностей объектов выполняется с помощью программного обеспечения XRISK с использованием метода предварительного анализа рисков (ПАР) и метода «Галстук-бабочка» (в горизонтальной плоскости).

Результаты. Дана оценка социально-экономического воздействия в случае аварии в углеводородной отрасли промышленности и рекомендации во избежание непредвиденных последствий.

Научная новизна. Впервые в SONATRACH программное обеспечение LOPA используется для моделирования аварийных сценариев в углеводородной отрасли промышленности. Последняя относится к отраслям с высоким уровнем риска, где каждый вид деятельности, будь то промышленный или коммерческий, подвержен самым разнообразным инцидентам или серьезным ситуациям, которые могут серьезно нарушить ее функционирование или даже повредить и уничтожить.

Практическая значимость. Определение чувствительных элементов, которые включают персонал станции, дежурных агентов ЦОС (цифровая обработка сигналов), субподрядчиков, то есть постоянно работающих сотрудников, в среднем 30 человек. Возникновение потенциальных крупных аварий, определенных в анализе рисков, приведет к остановке сжатия газа на станции Рурд Нусс. Таким образом, на уровне газопроводов происходит падение давления, что значительно снижает поток газа, а его степень и продолжительность будут зависеть от перезапуска станции. Кроме того, последствия повреждения соответствующего оборудования могут привести к значительным затратам на его замену в объективно необходимый срок.

Ключевые слова: XRISK, ALOHA, оценка аварийных ситуаций, предупреждение, углеводородная отрасль

Recommended for publication by Aissa Benselhoub. The manuscript was submitted 01.09.20. 